\title{
Paul Lugard (ed.): The international competition network at ten. Origins, accomplishments and aspirations
}

Intersentia, 2011, xvi + 424 pp, $€$ 82, ISBN: 978-9-40000-192-3

\section{Juergen G. Backhaus}

Judging by the index, perhaps one out of 23 chapters in this book on a core concept of the old law and economics takes a modern law and economics approach. However, even the chapter on ICN in the context of international anti-trust institutions reflects nothing justifying an extensive review in this journal. 